\title{
Measuring User Readiness of Web-based Encyclopedia for Kids based on Technology Readiness Index
}

\author{
Gita Indah Marthasari, Nur Hayatin, Evi Dwi Wahyuni, Rellanty Diana Kristy" \\ Fakultas Teknik, Program Studi Informatika, Universitas Muhammadiyah Malang, Malang, Indonesia \\ Email: 19ita@umm.ac.id, ${ }^{2}$ noorhayatin@umm.ac.id, ${ }^{3}$ evidwi@umm.ac.id, ${ }^{4}$ rellantidk@gmail.com \\ Email Penulis Korespondensi: rellantidk@gmail.com
}

\begin{abstract}
Abstrak-Pengukuran tingkat kesiapan pengguna dalam penggunaan teknologi baru adalah tahap yang diperlukan untuk menentukan keberhasilan penerapan teknologi. Hasil pengukuran ini dapat dimanfaatkan untuk mendapatkan rekomendasi pengembangan teknologi selanjutnya. Salah satu metode pengukuran adalah Technology Readiness Index (TRI). Metode tersebut dilakukan dengan menggunakan metode TRI lebih pribadi, di mana pengukuran dilakukan dengan menggunakan empat variabel, yaitu optimisme (optimisme), innovativeness (inovasi), ketidaknyamanan (incovenience), dan ketidak-amanan (insecurity). Pada penelitian ini, dilakukan pengukuran kesiapan pengguna terhadap aplikasi Anapedia. Anapedia adalah teknologi baru ensiklopedia berbasis web terbuka untuk anak-anak. Dalam penelitian ini, pengumpulan data dilakukan menggunakan instrumen berupa kuesioner yang dibagikan kepada siswa dan guru di sekolah dasar. Dari pengukuran tingkat kesiapan pengguna yang diambil dari 108 responden, ditemukan bahwa tingkat kesiapan pengguna Anapedia berada pada kesiapan teknologi tinggi dengan nilai 3,63.
\end{abstract}

Kata Kunci: Kesiapan Pengguna, Indeks Kesiapan Teknologi, Anapedia, Ensiklopedia Anak, Website

\begin{abstract}
Readiness level measurement of users who uses a new technology is needed to determine the success of technology to get a recommendation for further technology development. Technology Readiness Index (TRI) is a method to measure the user readiness level to a new technology. The approach is carried out by using the TRI method more personally, where measurements are made using four variables, i.e. optimism (optimism), innovativeness (innovation), discomfort (inconvenience), and insecurity (insecurity). This method will be implemented to the Anapedia application. Anapedia is a new technology of open web-based encyclopedia for children that is still needs developing and testing. Data collection in this study was carried out using a questionnaire research instrument that distributed to students and teachers in an elementary school. From the measurement of the level of readiness of users taken from 108 respondents, it was found that the level of readiness of Anapedia users was at a high technology readiness with value of 3.63.
\end{abstract}

Keywords: User Readiness, Technology Readiness Index, Anapedia, Children Encyclopedia, Website

\section{INTRODUCTION}

The successful implementing of a new technology depends on how users adopt that new technology. In this case, a readiness level measurement of users who still new in technology is needed to determine the success of technology [1][2]. So that, it can be used to get a recommendation for further the technology development. This is the purpose of this research that will measure the readiness level of users for a new app 'Anapedia'. Anapedia is an open web-based encyclopedia that developed specifically for children [3]. Anapedia is a technology that is still relatively new and it needs further development and testing. The testing has been done for this application, but only functional testing with the black box method. Though, the support from users are needed for new applications such as Anapedia as mentioned at the beginning of the paragraph. This is related to the readiness of users switch to a new technology. The success rate of applying new technologies can be influenced by the measurement of the level of readiness of users in the use of new technologies [1]. From the statement, it is known that is necessary to measure user readiness to find out the success of the application of Anapedia applications. The success of implementing new technologies depends on how the user adopts the technology. By measuring the readiness of users, the level of readiness of users is useful for further development [4].

The readiness level of users measured using methods that can describe the readiness of users. There are several methods for measuring technology readiness levels, i.e : Knowledge Management (KM)-Readiness [5][6], Net Ready[7], and Technology Readiness Index (TRI) [8][9][10]. These three methods are a measurement tool of user readiness level which use an organizational approach. But this study will use that measurement method for personal approach. So, the information that used does not need to reach a deep level such as leaders, but only in user level. So the method used to measure the readiness of users in this study is the TRI method. Technology Readiness (TR) is a method to measure people tendency to a new technology. While Technology Readiness Index (TRI) is the development of TR, that is a method to measure the user readiness level to a new technology [11]. The approach is carried out by using the TRI method more personally, where measurements are made using four variables [11], i.e. optimism (optimism), innovativeness (innovation), discomfort (inconvenience), and insecurity (insecurity).

Previous studies have used the TRI method to measure use readiness, such as the study of [12] who conducted research to find four psychological factors in adopting technology, i.e. optimism, innovativeness, discomfort, insecurity. Then these factors were assessed in the Technology Readiness Index (TRI). Another study using TRI is [7] that was motivated by the discovery of many problems in the use of the Oracle BI log system. This causes management to be hesitant about system updates. The study uses the Technology Readiness Index 
(TRI) method with a questionnaire adopted from Parasuraman, the total of questionnaire contains that used is 36 statements. And the results value is 2.37 that can be categorized as low technology readiness. The researcher provides overall recommendations to improve the readiness of Oracle Business Intelligence users. Anggraini, et.al [1] focused on knowing the readiness of users because of problems found during E-Learning trials at UIN Suska Riau and aTRI value of 3.36 is obtained, which means that the user is not ready yet and requires a preparation in a few aspects to achieve the successful implementation of E-Learning. In the application category, it requires a review so that it can produce categories that are in accordance with the application category in the Technology Readiness Index (TRI).

The purpose of this research is measuring the user readiness of Anapedia in a form of the level of readiness of users. This is important for further development of the application. The result also provide a recommendation to improve user readiness based on the analysis carried out, and also describe the level of readiness of users in Anapedia adoption. Measuring the readiness of users by using the Technology Readiness Index (TRI) will be known that the new technology can be well-received by the user or not and can also find out whether the user will continue to use the new technology [13]. The method of data collection in this study used a survey to convey a series of previously formulated questions and a specific sequence in a structured questionnaire to one sample of individuals chosen to represent a defined population.

The research [2] have conducted a study to find four psychological factors in the adoption of technology, i.e. optimism, innovativeness, discomfort, and insecurity. Then these factors were assessed in the Technology Readiness Index (TRI). Furthermore, the use of other TRIs is focused on knowing the readiness of users because of some problems has been found during the E-Learning operational [1][14]. Shirahada, et.al measuring readiness for the use of online public services by elderly users in Japan, and the United Kingdom [14]. This study aims to determine the primary motivation of elderly users in using online public services by considering personal characteristics of both internal and external objects. The study was conducted by distributing questionnaires to 382 respondents aged over 65 years in both countries. Analysis conducted using the Structural Equation Model shows that the motivation to use online public services by elderly users is strongly influenced by the level of well-being of life supported by good social and family interactions.

Technology Readiness Index (TRI) is the development of Technology Readiness (TR). TR is a tendency for someone to use and accept technology to be able to complete their work, not to see whether the technology is controlled or not [1][10][15]. While the Technology Readiness Index (TRI) is an index used to measure the readiness of users towards new technologies that will be used to achieve goals in daily life and work [11]. Referring to research conducted by Parasuraman, TRI can be used to measure the readiness of users in using new technology by using four personality variables, i.e. : optimism (a positive attitude towards technology and believes that technology will improve control, flexibility, and efficiency in life), innovativeness/innovation (the attitude of being devoted to use the first time a new product or technology; innovation is the level where users use new ideas that are relatively earlier than other users of the system), discomfort/inconvenience (a difficult attitude to control and tends to be overwhelmed or not confident when dealing with a new technology), and insecurity (a suspicion of technological security and reasons for security of personal data.). The Technology Readiness Index (TRI) has three categories in its application, i.e. : low, medium, and high. User readiness is considered low if the TRI value is equal to or less than 2.89 (TRI $=<2.89)$, medium if the TRI value is between 2.90 to $3.51(2.90=<\mathrm{TRI}=<3.51)$, and high if the TRI value is more than 3.51 (TRI> 3.51).

\section{RESEARCH METHODOLOGY}

In this study, the research method used can be seen in Fig. 1. The method of data collection in this study used a survey to convey a series of previously formulated questions and a specific sequence in a structured questionnaire to one sample of individuals chosen to represent a defined population based on research [1]. TRI has four exogenous variables that can significantly influence endogenous variables bound to TR. The exogenous variable consists of two variables with the user's positive perception of technology that can increase the TR level of the user, namely optimism and innovativeness. Two other exogenous variables are negative user perception, namely discomfort and insecurity [12][16]. Positive variables (optimism and innovation) encourage people to use product / service technology and hold positive attitudes towards technology. Negative variables (inconvenience and insecurity) inhibit technology adoption by the people [2]. As in the research model in Fig. 2, optimism and innovation play a role as contributors that give positive value to user readiness. While discomfort and insecurity become inhibitors or inhibitors of the adoption of a technology itself. 
ISSN 2614-5278 (media cetak), ISSN 2548-8368 (media online)

Available Online at https://ejurnal.stmik-budidarma.ac.id/index.php/mib DOI 10.30865/mib.v4i2.2005

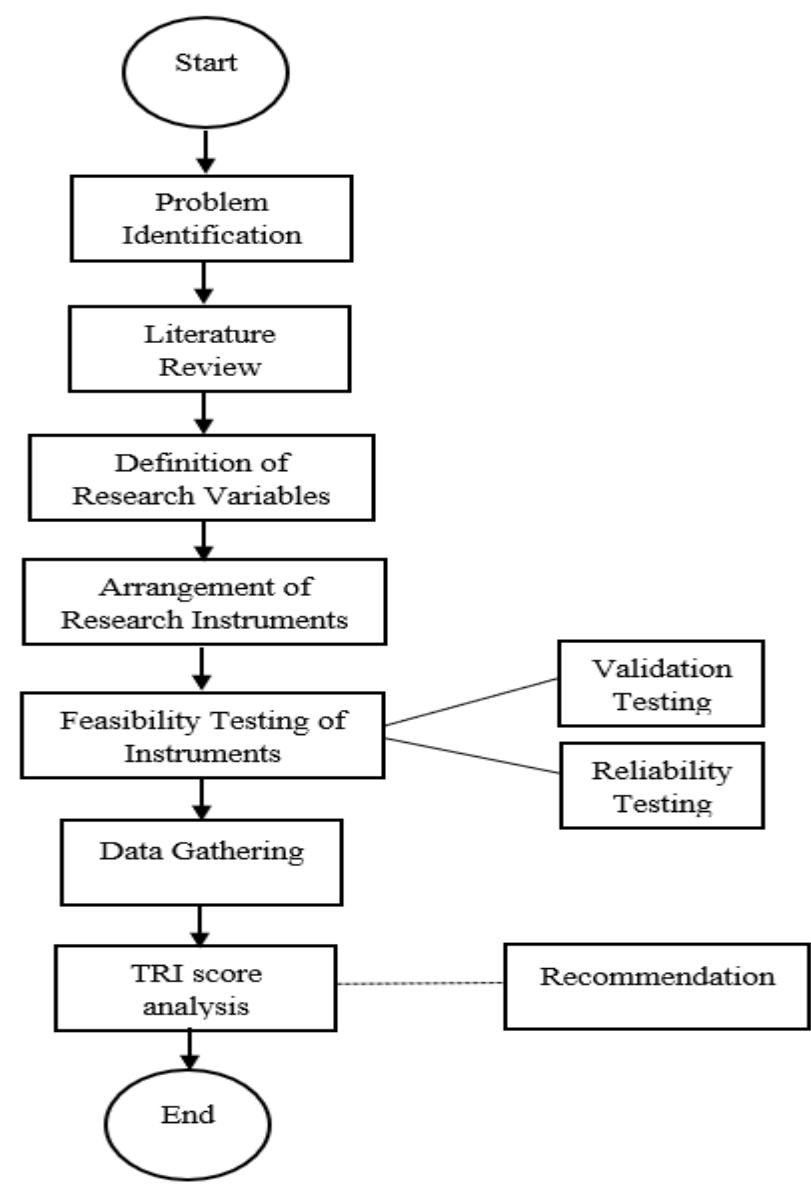

Figure 1. Research Methodology

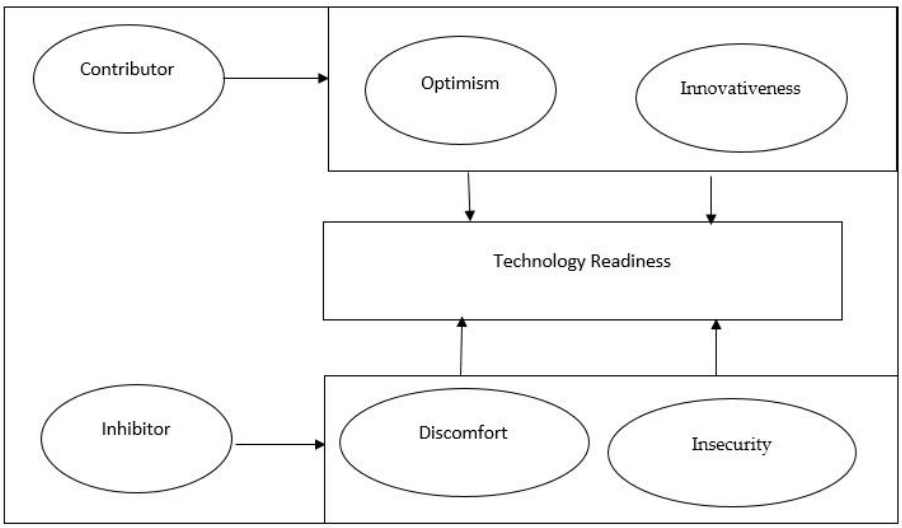

Figure 2. Research Model

\subsection{Research Instrument}

The research instrument used is questionnaire form which is adapted from the research instrument conducted by Parasuraman. Adaptation is done to adjust the existing research instrument with the research conducted. The questionnaire consists of 4 variables and 36 indicators, each variable has an item, i.e. 10 items of the optimism variable, 7 items of innovativeness, 10 items of the discomfort variable, and 9 items of the insecurity variable. The calculation scale used is the Likert scale. Likert scale is a scale used to measure attitudes and opinions of individuals and groups towards a social phenomenon where the answer has a gradation of values from very positive to very negative for each instrument item [17]. The Likert scale can be seen in Table 1. Based on the results of validity testing, 30 valid research instruments were obtained. The research instrument can be seen in Table 2 . 
Table 1. Likert Scale

\begin{tabular}{ll}
\hline Answer Options & Value \\
\hline Strongly Disagree & 1 \\
Disagree & 2 \\
Neutral & 3 \\
Agree & 4 \\
Strongly agree & 5 \\
\hline
\end{tabular}

Table 2. Research Instruments

\begin{tabular}{|c|c|c|}
\hline No & Domain & Statement \\
\hline 1 & Optimism & $\begin{array}{l}\text { - Children encyclopedia provides convenience in everyday life. } \\
\text { - I feel comfortable doing a search using a children's encyclopedia because there } \\
\text { is no time limit in its use. } \\
\text { - I prefer to use children encyclopedia because the children's encyclopedia is a } \\
\text { more advanced technology. } \\
\text { - I like to use children encyclopedia because it can be tailored to my needs. } \\
\text { - Children encyclopedia can increase my creativity. } \\
\text { - Children encyclopedia gives me freedom in search. } \\
\text { - I feel confident that the children's encyclopedia will follow the instructions I } \\
\text { give. }\end{array}$ \\
\hline 2 & $\begin{array}{l}\text { Innovative } \\
\text { ness }\end{array}$ & $\begin{array}{l}\text { - I was the first person to know the children's encyclopedia compared to my } \\
\text { friends. } \\
\text { - I know the development of children's encyclopedias without the help of others. } \\
\text { - I really enjoy the time to look for articles in the children's encyclopedia. } \\
\text { - I feel able and have no problems using the children's encyclopedia. }\end{array}$ \\
\hline 3 & Discomfort & $\begin{array}{l}\text { - I feel the available guide does not help me. } \\
\text { - Sometimes I think a children's encyclopedia complicates my work. } \\
\text { - Guides in using children's encyclopedia are difficult to understand. } \\
\text { - Sometimes I feel used by others who understand more about children's } \\
\text { encyclopedia. } \\
\text { - I prefer the children's encyclopedia with a simple design with many features } \\
\text { rather than attractive designs but few features. } \\
\text { - I feel uncomfortable using a children's encyclopedia, because I am embarrassed } \\
\text { if I experience difficulties in front of many people. } \\
\text { - I am not comfortable using a children's encyclopedia for fear of being damaged. } \\
\text { - I am not comfortable using a children's encyclopedia for fear of disrupting my } \\
\text { - I I am noalth and safety. } \\
\text { - Children's encyclopedias are always problematic when I use them. }\end{array}$ \\
\hline 4 & Insecurity & $\begin{array}{l}\text { - I feel unsafe to give my identity through a children's encyclopedia. } \\
\text { - I feel unsafe if my personal data is stored in a children's encyclopedia. } \\
\text { - I do not believe sending information through a children's encyclopedia for fear } \\
\text { that the information is known to others. } \\
\text { - I am not confident if I have to find information on the children's encyclopedia. } \\
\text { - Information obtained from search results in the encyclopedia must have a clear } \\
\text { source. } \\
\text { - Every time the process takes place automatically I must always check back to } \\
\text { make sure the children's encyclopedia does not make mistakes. } \\
\text { - Human touch is important when searching for children's encyclopedia. } \\
\text { - When I do a search, I prefer to interact with humans rather than searching for } \\
\text { children's encyclopedia. } \\
\text { - I do not believe if the information I send will arrive. }\end{array}$ \\
\hline
\end{tabular}

\subsection{Data Collection}

Data is an important aspect in this study. Data collection in this study was carried out using a questionnaire research instrument. Questionnaires were distributed to respondents using an even distribution with the assumption that the distribution of questionnaires could represent all students and elementary school teachers at Bandungrejosari 2 
Elementary School in Malang. According to the results of observations and interviews, students and teachers of Bandungrejosari 2 State Elementary School were less interested in using a new technology therefore it requires measurement before applying the Anapedia application. The population of this study is the student of grade five and six, and teachers at SDN Bandungrejosari 2 Malang that is equal to 180 persons. This number consists of 118 students of grade 5, 78 students of grade 6, and 19 teachers. The number of samples was determined using a Harry King nomogram. For a population of 180 with an error tolerance of $10 \%$ the number of samples used is 108 . The technique used is Proportionate Stratified random sampling. The sampling technique used when the population has a stratified but proportional element [18][19][5]. The characteristics of the population members sampled consist the age range of Anapedia users at SDN Bandungrejosari 2 Malang. The age range is used to determine respondents who play a role as contributors, and also respondents who play a role as users. The age range of contributors is 22-60 years, and the age range of Anapedia users is between the ages of 10-14 years. The sample allocation that has been taken is divided according to the number of Anapedia users using proportional allocation. Proportional allocation is used to divide the sample into each group of users. From the calculations that have been done, the sample is divided into 97 respondents for students and 11 for teachers or contributors. The proportional allocation formula uses equation 1 [20], $N i$ is the number of population groups, $N$ is the total population and $\mathrm{n}$ is the number of sample.

$$
n=\frac{\mathrm{Ni}}{N} \times n
$$

\section{RESULT AND DISCUSSION}

Data analysis is carried out when the required research data has been obtained and has gone through the testing phase of validity and reliability. The data analysis uses inferential statistics to collect, process, present, and analyze quantitative data [7]. The results of this calculation will be used to support conclusions for the problems in the research conducted. After the research data been obtained from respondents, we conduct the validity and reliability testing before analyse it with the inferential statistic method. Through the method, a conclusion will be obtained. The conclusion must cover all the discussion topics from the research then summarized to answer the statement on the research. From the conclusion, any obstacles to the implementation of Anapedia will be found. These conclusions can produce recommendations for the problems that exist in Anapedia, so that they can be followed up more quickly.

\subsection{Validity Testing}

Validity testing is done to measure the feasibility of the questionnaire, this study uses two stages of validity testing. The first test aims to measure the validity of the research instrument (content validity) as measured by the Pearson correlation coefficient using Equation 2 which is called product moment [19], while the variable $r$ is the correlation between items of statements with $a$ total score. While $x$ is the independent variable, $y$ is the dependent variable, and $n$ is the number of assessments obtained. While the formula of $\sum x y$ is the number of multiplications between the independent variable and the dependent variable, $\sum x^{2}$ is the sum of squares of free values, $\sum y^{2}$ is the number of squares of the bound value, and $\sum x^{2}$ and $\sum y^{2}$ is the number of values of the bound variable squared.

$$
r=\frac{n\left(\sum x y\right)-\left(\sum x\right)\left(\sum y\right)}{\sqrt{\left(n \sum x^{2}-\left(\sum x\right)^{2}\right)\left(n \sum y^{2}-\left(\sum y\right)^{2}\right)}}
$$

For this research, statement items will act as independent variables, while the total score of statements will act as dependent variables. The score of each statement item will be correlated with the total score (internal itemtotal correlation). Next, to decide whether the statement items are valid, $t$ test is performed by comparing $t$ count with $t$ table using the desired significance value and the degree of freedom $n$-2, then calculate the $t$-counts using equation 3 where $r$ is the Pearson correlation coefficient.

$$
t=\frac{r \sqrt{(n-2)}}{\sqrt{(1-r 2)}}
$$

The instrument item validation decision can be made with the following conditions: 1) The instrument item is called valid if the $t$ value is greater than or equal to the table then the instrument items can be used; 2) The instrument item is valid if the $t$ value is smaller than $t$ table and the item cannot be used.

\subsection{Reliability Testing}

Reliability testing aims to determine the degree of consistency and stability of the data, so that the measurement instrument or tool should have relatively consistent measurement results. Reliability testing can be done using Cronbach's alpha [21]. This method does not divide the statement into two, but all statement items are correlated directly. $C A$ is the Cronbach's Alpha Coefficient where $k$ is the number of questions in item, the formula $\sum \sigma_{b}^{2}$ is 
ISSN 2614-5278 (media cetak), ISSN 2548-8368 (media online)

Available Online at https://ejurnal.stmik-budidarma.ac.id/index.php/mib DOI 10.30865/mib.v4i2.2005

the number of item variance, and $\sigma_{t}^{2}$ is the total variance. To decide which instrument to use reliably, then a comparison must be made between the Cronbach's Alpha coefficients obtained with the $r$ table. If the value of the alpha coefficient greater than 0.6 then it is considered as a valid valid instruments [7].

$$
C A=\left[\frac{k}{k-1}\right]\left[1-\frac{\sum \sigma_{b}^{2}}{\sigma_{t}^{2}}\right]
$$

\subsection{Analysis of User Readiness}

TRI analysis is conducted to determine the level of readiness of users by grouping data according to the research variables. It aims to get the TRI value as a whole in the form of the mean value. The Technology Readiness Index (TRI) calculation method is done by calculating the mean on each statement item. The mean value is obtained from the multiplication of weights (f) in each statement with the specified Likert scale value (n), then divided by the number of respondents. Each variable has a total weight of $25 \%$ which is then divided by the number of statements on each variable. To get a TRI score on each variable, the mean value of the statement $\mathrm{n}$ is multiplied by the weight of the total that has been obtained. The total TRI score is obtained from the total number of total scores for each statement on each variable. To get a total TRI score, it is necessary to add up the total score of each variable. The calculation for the "optimism" variable can be seen in Table 3 where the value of the variable is the sum of the overall score of 1.036953 . The table is the value of the total score of each variable and also the TRI score in the following Table 4.

Table 3. Calculation for Variable "Optimism"

\begin{tabular}{|c|c|c|c|c|c|c|}
\hline \multirow[t]{2}{*}{ Statement } & \multicolumn{2}{|c|}{ Answer } & \multirow[t]{2}{*}{ fxn } & \multirow[t]{2}{*}{ Mean } & \multirow[t]{2}{*}{ Weight } & \multirow[t]{2}{*}{ Score } \\
\hline & $\mathbf{f}$ & $\mathbf{n}$ & & & & \\
\hline \multirow[t]{5}{*}{1} & 1 & 2 & 2 & \multirow{5}{*}{4,259259} & \multirow{5}{*}{$3,57 \%$} & \multirow{5}{*}{0,152056} \\
\hline & 2 & 0 & 0 & & & \\
\hline & 3 & 15 & 45 & & & \\
\hline & 4 & 42 & 168 & & & \\
\hline & 5 & 49 & 245 & & & \\
\hline Jumlah & & 108 & 460 & & & \\
\hline \multirow[t]{5}{*}{3} & 1 & 0 & 0 & \multirow{5}{*}{4,157407} & \multirow{5}{*}{$3,57 \%$} & \multirow{5}{*}{0,148419} \\
\hline & 2 & 7 & 14 & & & \\
\hline & 3 & 22 & 66 & & & \\
\hline & 4 & 26 & 104 & & & \\
\hline & 5 & 53 & 265 & & & \\
\hline Jumlah & & 108 & 449 & & & \\
\hline \multirow[t]{5}{*}{4} & 1 & 2 & 2 & \multirow{5}{*}{4,111111} & \multirow{5}{*}{$3,57 \%$} & \multirow{5}{*}{0,146767} \\
\hline & 2 & 2 & 4 & & & \\
\hline & 3 & 24 & 72 & & & \\
\hline & 4 & 34 & 136 & & & \\
\hline & 5 & 46 & 230 & & & \\
\hline Jumlah & & 108 & 444 & & & \\
\hline \multirow[t]{5}{*}{5} & 1 & 0 & 0 & \multirow{5}{*}{4,333333} & \multirow{5}{*}{$3,57 \%$} & \multirow{5}{*}{0,1547} \\
\hline & 2 & 0 & 0 & & & \\
\hline & 3 & 16 & 48 & & & \\
\hline & 4 & 40 & 160 & & & \\
\hline & 5 & 52 & 260 & & & \\
\hline Jumlah & & 108 & 468 & & & \\
\hline \multirow[t]{5}{*}{7} & 1 & 1 & 1 & \multirow{5}{*}{4,138889} & \multirow{5}{*}{$3,57 \%$} & \multirow{5}{*}{0,147758} \\
\hline & 2 & 2 & 4 & & & \\
\hline & 3 & 24 & 72 & & & \\
\hline & 4 & 35 & 140 & & & \\
\hline & 5 & 46 & 230 & & & \\
\hline Jumlah & & 108 & 447 & & & \\
\hline 8 & 1 & 2 & 2 & & & \\
\hline & 2 & 2 & 4 & & & \\
\hline & 3 & 21 & 63 & 4,101852 & $3,57 \%$ & 0,146436 \\
\hline & 4 & 41 & 164 & & & \\
\hline & 5 & 42 & 210 & & & \\
\hline Jumlah & & 108 & 443 & & & \\
\hline 10 & 1 & 3 & 3 & 3,944444 & $3,57 \%$ & 0,140817 \\
\hline
\end{tabular}


JURNAL MEDIA INFORMATIKA BUDIDARMA

Volume 4, Nomor 2, April 2020, Page 294-301

ISSN 2614-5278 (media cetak), ISSN 2548-8368 (media online)

Available Online at https://ejurnal.stmik-budidarma.ac.id/index.php/mib

DOI $10.30865 /$ mib.v4i2.2005

\begin{tabular}{ccccccc}
\hline \multirow{2}{*}{ Statement } & & Answer & f x n & Mean & Weight & Score \\
\cline { 2 - 4 } & $\mathbf{f}$ & $\mathbf{n}$ & & & \\
\hline 2 & 2 & 4 & & \\
\hline & 3 & 34 & 102 & & \\
\hline Jumlah & 5 & 28 & 112 & & \\
\hline
\end{tabular}

Table 4. TRI Score Table

\begin{tabular}{ll}
\hline Variable & Value \\
\hline Optimism & 1,036953 \\
Innovativeness & 0,925347 \\
Discomfort & 0,88426 \\
Insecurity & 0,7551 \\
\hline TRI & $\mathbf{3 , 6 0 1 6 5 9}$
\end{tabular}

From the measurement of the level of readiness of users taken from 108 respondents, it was found that the level of readiness of Anapedia users was at a high technology readiness with value of 3.63. This value is composed of 4 variables. The following is an explanation of the variable:

a. Optimism

The optimism contributes a value of 1,036953 . This value is the largest contribution to the TRI total score. This shows that the teachers and students of SDN Bandungrjosari 2 Malang have a positive view of Anapedia. Users believe that Anapedia will have a positive influence on everyday life.

b. Innovativeness

The innovativeness gives a value of 0.925347 . This value is the second largest value in contributing to the TRI total score. This value shows that the teachers and students of Bandungrejosari 2 Elementary School have innovative qualities in adopting and utilizing Anapedia in their daily lives.

c. Discomfort

The discomfort contributes a value of 0.88426 for TRI total score. Discomfort and insecurity are variables that must be assessed in reverse (reverse coding) because they contain negative values against the TRI value generated. From the value obtained, it means that the teachers and students of Bandungrejosari 2 Elementary School have a low level of comfort towards adopting Anapedia.

d. Insecurity

Insecurity gives the smallest contribution with a value of 0.7551 for a total TRI score. This value means that the teachers and students of Bandungrejosari 2 Elementary School have a low level of security towards technology.

\section{CONCLUSION}

Based on the results of the research that has been done, it can be concluded that the encyclopedia users of the SDN Bandungrejosari 2 Malang obtained a score of 3.6. This value means the child encyclopedia user in the adoption of Anapedia is in the category of High Technology Readiness. Users already have high readiness in adopting Anapedia. Judging from the value of the optimism variable that contributes the greatest value to the total TRI score can be concluded if the user believes that by adopting a child encyclopedia in this study is Anapedia the user will be given a positive impact. Then from the innovativeness variable which means the user has the desire to innovate. Users have a desire to use new technology and also explore it. Of the two variables that have negative values can be concluded if discomfort is the biggest obstacle in adopting Anapedia. From the practical perspective, the results of this study are very useful for the development of Anapedia websites in general and the development of webbased encyclopedias in particular. Website developers should design better interface designs, so that children as users feel more comfortable when interacting with applications. The developer needs to implement a special usability guideline for the encyclopedia website and to evaluate whether the interface is suitable for the needs of children.

\section{REFERENCES}

[1] Anggraini and D. Suryadi, "Pengukuran Tingkat Kesiapan Penerapan E-learning menggunakan TRI (Technology Readiness Index), studi kasus : UIN Suska Riau,” J. Sist. Inf., vol. 5, no. 3, pp. 237-241, 2015.

[2] M. A. Hemdi, S. A. S. Rahman, and M. H. Hanafiah, "Airport self-service check-in: The influence of technology readiness on customer satisfaction Airport self-service check-in: The influence of technology readiness on customer satisfaction," in Proceedings of the 3rd International Hospitality and Tourism Conference \& 2 nd International Seminar 
on Tourism, 2016, no. January.

[3] N. Hayatin et al., "Anapedia - An Open Web-based Encyclopedia for Indonesian Children,” J. Inf. Syst. Eng. Bus. Intell., vol. 5, no. 1, pp. 48-56, 2019.

[4] A. A. Hamid and Z. Mansor, "Client's Readiness Assessment Success Factors for Outsourcing Software Projects," Int J. Adv. Sci. Eng. Inf. Technol., vol. 6, no. 6, pp. 820-827, 2016.

[5] P. Lynn, "The Advantage and Disadvantage of Implicitly Stratified Sampling," methods, data, Anal., vol. 13, no. 2, pp. 253-266, 2019.

[6] S. Ikbal, A. Kurniawati, and N. Ambarsari, "Knowledge management system implementation readiness measurement in PDII LIPI based on people and organizational structure factors," Procedia Manuf., vol. 4, no. Iess, pp. 216-223, 2015.

[7] A. LAZUARDI, "TINGKAT KESIAPAN (READINESS) PENGADOPSIAN TEKNOLOGI INFORMASI: STUDI KASUS PANIN BANK," 2013.

[8] M. S. Summak, M. Ba, and M. Samanc, "Technology readiness of primary school teachers : A case study in Turkey," vol. 2, pp. 2671-2675, 2010.

[9] S. Sun, P. Lee, and R. Law, "Impact of cultural values on technology acceptance and technology readiness," no. March, 2018.

[10] M. A. Nugroho and M. A. Fajar, "Effects of Technology Readiness Towards Acceptance of Mandatory Web-Based Attendance System," Procedia Comput. Sci., vol. 124, pp. 319-328, 2018.

[11] A. Parasuraman and C. L. Colby, "An Updated and Streamlined Technology Readiness Index: TRI 2.0," J. Serv. Res., no. June, pp. 0-16, 2014.

[12] W. Ngwa, T. Ngoma, and D. Napitupulu, "Analysis of user readiness toward ICT usage at small medium enterprise in south tangerang Analysis of user readiness toward ICT usage at small medium enterprise in south tangerang," J. Phys. Conf. Ser., vol. 1007, 2018.

[13] M. Son and K. Han, "Beyond the technology adoption : Technology readiness effects on post-adoption behavior is," $J$. Bus. Res., vol. 64, no. 11, pp. 1178-1182, 2011.

[14] M. Smith and N. S. Walford, "Assessing the user response to differences in functionality when visualising 3D models of cultural heritage sites using the Technology Readiness Index," Digit. Appl. Archaeol. Cult. Herit., vol. 10, 2018.

[15] M. A. Badri, J. Mohaidat, and A. Al Rashedi, "Technology Readiness of School Teachers - An Empirical Study of Measurement and Segmentation," Ind. Eng. Manag., vol. 2, no. 4, 2013.

[16] H. Hallikainen and T. Laukkanen, "HOW TECHNOLOGY READINESS EXPLAINS ACCEPTANCE AND B2B HEALTHCARE SECTOR ?," in PACIS 2016 Proceedings, 2016, p. 294

[17] A. Joshi and D. K. Pal, "Likert Scale : Explored and Explained Likert Scale : Explored and Explained," no. January, 2015.

[18] S. Sariah and S. Hassan, "Measuring attitude towards learning science in Malaysian secondary school context: implications for teaching," Int. J. Sci. Educ., vol. 0, no. 0, pp. 1-16, 2018.

[19] H. Xu and Y. Deng, "Dependent Evidence Combination Based on Shearman Coefficient and Pearson Coefficient," IEEE Access, vol. 6, pp. 11634-11640, 2018.

[20] D. A. KUSUMANINGTYAS, "THE APPLICATION OF ORDINAL LOGISTIC REGRESSION ON FINANCIAL LITERACY," Institut Pertanian Bogor, 2015.

[21] Y. Wang, K. Kam, F. So, and B. A. Sparks, "Technology Readiness and Customer Satisfaction with Travel Technologies : A Cross-Country Investigation," J. Travel Res., vol. 1, no. 15, 2016. 